\title{
СТАТЬИ
}

DOI: https://doi.org/10.15688/nav.jvolsu.2018.2.1

UDC 904

Submitted: 27.09 .2018

LBC 63.4(2)

Accepted: 05.11.2018

\section{HORSE FOREHEAD PIECES FROM NOMADIC BARROWS OF THE SCYTHIAN TIME IN THE SOUTHERN URALS ${ }^{1}$}

\author{
Vladimir N. Myshkin \\ Samara State University of Social Sciences and Education, Samara, Russian Federation
}

\begin{abstract}
The paper is devoted to the description of horse forehead pieces, which were used by the nomads of the Southern Urals in the $6^{\text {th }}-4^{\text {th }}$ centuries BC for protecting the horse's head and / or decorating bridle. The research is based on the analysis of sample consisting of 47 finds. The author proposes the typology of the items under consideration, characterizes the types of lamellar forehead pieces with and without zoomorphic images, rodlike and rod-lamellar forehead pieces, forehead pieces in the form of zoomorphic images, representing a round sculpture. All the finds are divided into two chronological groups. The first group includes forehead pieces, which were part of horse equipment mainly at the end of the $6^{\text {th }}-5^{\text {th }}$ centuries BC. This period was charactized by the prevalence of forehead pieces in the form of fairly large trapezoidal or subrectangular plates depicting the heads of prey birds in profile on one or both short sides. The second group unites the items referring to the end of the $5^{\text {th }}-$ $4^{\text {th }}$ centuries BC. The most common type in this period is represented with forehead pieces in the form of a rod, the upper part of which is bent as a loop and ends with a spherical thickening, and the lower part is loose in the form of an elongated plate. A significant difference in the nomenclature of the two chronological groups of the horse forehead pieces has been revealed. This was probably due to the ethnocultural changes that took place in the nomadic society of the Southern Urals in the late $5^{\text {th }}$ and early $4^{\text {th }}$ centuries BC, including those in the nature and direction of external relations.

Key words: Early Iron Age, Southern Urals, barrows, nomads, Scythian time, horse equipment, horse forehead pieces.

Citation. Myshkin V.N., 2018. Horse Forehead Pieces from Nomadic Barrows of the Scythian Time in the Southern Urals. The Lower Volga Archaeological Bulletin, vol. 17, no. 2, pp. 5-17. (in Russian). DOI: https:// doi.org/10.15688/nav.jvolsu.2018.2.1
\end{abstract}

УДК 904

ББК 63.4(2)

Дата поступления статьи: 27.09.2018

Дата принятия статьи: 05.11.2018

\section{КОНСКИЕ НАЛОБНИКИ ИЗ КОЧЕВНИЧЕСКИХ КУРГАНОВ СКИФСКОГО ВРЕМЕНИ НА ЮЖНОМ УРАЛЕ ${ }^{1}$}

\section{Владимир Николаевич Мышкин}

Самарский государственный социально-педагогический университет, г. Самара, Российская Федерация

Аннотация. Статья посвящена характеристике конских налобников, которые использовались кочевниками Южного Приуралья в VI-IV вв. до н.э. для защиты головы коня и / или украшения узды. Работа основана на анализе выборки, состоящей из 47 находок. Предложена типология налобников. Приведена характеристика типов пластинчатых налобников с зооморфными изображениями и без них, стержневидных и стержневид- 
но-пластинчатых налобников, налобников в виде зооморфных изображений, представляющих собой круглую скульптуру. Все находки разделены на две хронологические группы. В одну группу включены налобники, которые входили в состав конского снаряжения преимущественно в конце VI - V в. до н.э. В этот период наиболее распространенными были налобники в виде достаточно крупных трапециевидных или подпрямоугольных пластин с изображением голов хищных птиц в профиль на одной или обеих коротких сторонах. Во вторую объединены экземпляры, бытование которых у кочевников приходится в основном на время в пределах конца V - IV в. до н.э. Наиболее распространенным типом в этот период являются налобники в виде стержня, верхняя часть которого согнута петлей и заканчивается шаровидным утолщением, а нижняя раскована в виде удлиненной пластины. Констатировано значительное различие номенклатуры двух хронологических групп конских налобников. Это, вероятно, было связано с этнокультурными изменениями, происходившими в обществе кочевников Южного Приуралья в конце $\mathrm{V}$ - начале IV в. до н.э., в том числе в характере и направленности внешних связей.

Ключевые слова: ранний железный век, Южное Приуралье, курганы, кочевники, скифское время, снаряжение коня, конские налобники.

Цитирование. Мышкин В. Н., 2018. Конские налобники из кочевнических курганов скифского времени на Южном Урале // Нижневолжский археологический вестник. Т. 17, № 2. С. 5-17. DOI: https://doi.org/10.15688/ nav.jvolsu.2018.2.1

\section{Введение}

В археологической литературе, посвященной изучению культуры кочевников Южного Приуралья, среди принадлежностей конского снаряжения выделяют налобники - детали оголовья, крепившиеся на налобном ремне и служившие для защиты головы коня и / или выполнявшие декоративные функции. В 60 -е гг. $\mathrm{XX}$ в. К.Ф. Смирнов в ряде работ обобщил накопленные к тому времени материалы, связанные с развитием всадничества у кочевых скотоводов в степях Южного Приуралья и Поволжья в первой половине - середине I тыс. до н.э. В частности, среди предметов конского снаряжения из кургана у хут. Черниговского, кург. 5 могильника Пятимары II и кург. 1 у с. Покровка (раскопки 1911 г.) были выделены находки, которые могли использоваться в качестве налобников [Смирнов, 1961, с. 94; Смирнов, Петренко, 1963, с. 29-30, табл. 17,3,4,29,43].

Н.Е. Берлизов, рассматривая древности ранних кочевников Сарматии, в том числе и скотоводческих племен Южного Приуралья, выделил два типа этой детали уздечного набоpa. К типу 1 он отнес серебряный парадный налобник с изображением головы хищника, к типу 2 - налобники с загнутым вперед крючком, представленные двумя вариантами: с вытянутой расширяющейся книзу подтреугольной лопастью, крючком в верхней части и петлей в средней и стержневидные налобники, завершающиеся крючком и имеющие петлю у основания крючка [Берлизов, 2011, с. 106, табл. 44Е].
М.А. Очир-Горяева разделила налобники на три группы. В первую группу ею объединены удлиненные бляшки с профилем птицы на верхнем крае, являющиеся составной частью комплекса предметов конской амуниции конца VI - V в. до н.э. Во вторую группу автором включены прямоугольные пластины с геометрическим орнаментом и без него, которые встречаются среди предметов конского снаряжения комплексов $\mathrm{V}$ в. до н.э. и конца $\mathrm{V}-\mathrm{IV}$ в. до н.э. Третья группа - крючковидные налобники, являющиеся характерной частью уздечных наборов конца V - IV в. до н.э. [Очир-Горяева, 2012, с. 260-271].

Публикация новых находок налобников позволяет вновь обратиться к их исследованию, включающему выделение типов этих деталей конского снаряжения и определение времени их бытования у кочевников Южного Приуралья.

\section{Типы налобников и время их распространения}

Выделение типов осуществлялось по сочетанию следующих признаков.

Форма по соотношению длины, иириныл и выссотыл: 1 - пластинчатый; 2 - стержневидный; 3 - стержневидно-пластинчатый.

Форма пластин в плане: 1 - прямоугольная или подпрямоугольная; 2 - трапециевидная; 3 - квадратная или подквадратная; 4 круглая или овальная; 5 - ромбовидная; 6 «лабрисовидная»; 7 - сложная, сочетающая круглую и прямоугольную формы. 
Форма пластин в профильной проекизии: 1 - плоская, уплощенная; 2 - полусферическая; 3 - плоская в сочетании с полусферической.

Художественное оформление внешней поверхности: 1 - зооморфные изображения; 2 - геометрический орнамент; 3 - нет.

Наличие зооморфных изображений: 1 - есть; 2 - нет.

Вид скульптурных изображений: 1 рельеф; 2 - круглая скульптура.

Мотив зооморфного изображения: 1 голова хищной птицы / грифона; 2 - фигура свернувшегося кольцом хищника; 3 - фигура припавшего на передние лапы хищника с вывернутой задней частью и закинутой на спину лапой; 4 - изображение, которое может быть интерпретировано как фигура копытного с подогнутой задней ногой и вывернутой передней ногой (ноги зверя при этом трансформированы в головы птиц), а также как обособленная нога со свисающим копытом; 5 - протома горного козла.

Вид геометрического орнамента: 1 углубления в виде концентрических окружностей; 2 - концентрические валики; 3 - отверстия треугольной формы; 4 - дуговидные отверстия или выемки; 5 - параллельно расположенные углубления в виде прямых линий.

Работа основана на анализе выборки, состоящей из 47 находок. Выделены следующие типы налобников.

\section{1. Пластинчатые налобники}

1.1. Пластинчатые налобники, украшенные зооморфными изображениями

Тип 1.1.1. Металлические налобники, выполненные в виде трапециевидных или подпрямоугольных с округлыми углами пластин, короткая сторона которых (или обе), как правило, оформлены в виде стилизованных изображений голов хищных птиц или грифонов в профиль (рис. 1,1-6). В одном случае из-за коррозии поверхности можно только предполагать наличие такого изображения (рис. 1,4 ). Пластины налобников достаточно большие, их длина составляет 8-12 см, ширина 2-4,6 cм. Учтены девять налобников этого типа. Три из них обнаружены в памятниках, датированных К.Ф. Смирновым временем в пределах второй половины VI в. до н.э.: два (рис. 1,2-3)в кургане у хут. Черниговский, один (рис. 1,4)- в погр. 2 кург. 19 могильника Новый Кумак [Смирнов, 1961, с. 88, рис. 49,9; 1964, с. 39-40, рис. $9,1 e ; 1977$, с. 26 , рис. 11,20$]$. Один экземпляр (рис. 1,5) найден в могильнике Бесоба (кург. 9), один (рис. 1,1) - в кург. 2 могильника Покровка 2 и четыре очень сходных (рис. 1,6) - в кург. 1 у с. Покровка, раскопанном в 1911 году. Два первых комплекса датированы концом VI - V в. до н.э., последний ранним V в. до н.э. [Кадырбаев, 1984, с. 9091 , рис. 5,3; Моргунова, Трунаева, 1993, с. 1617 , рис. 18,16 ; Смирнов, 1964 , с. 47 , рис. $16,1 a]$.

Тип. 1.1.2. Металлические налобники (рис. 1,7-10), выполненные в виде удлиненных пластин сравнительно небольших размеров. Их длина, судя по нефрагментированному экземпляру, составляет около 5,6 см, ширина 1,4-1,6 см. Короткие верхние стороны пластин имеют завершение в виде полусферических блях и стилизованного изображения профиля головы хищной птицы. Изображение птичьей головы расположено в той же плоскости, что и остальная часть пластины. Нижняя часть пластины, сохранившейся целой, имеет округлое завершение. В верхней части пластин на их внутренней стороне имеются петли или выступ-штифт для крепления к ремням оголовья. Петли располагаются по продольной оси пластин, выступ - поперек. К данному типу могу быть отнесены четыре находки из кург. 5 могильника Пятимары II [Смирнов, 1961, с. 94, рис. 54]. Как налобники эти находки были интерпретированы К.Ф. Смирновым [Смирнов, 1961, с. 94] и впоследствии М.А. Очир-Горяевой [Очир-Горяева, 2006, рис. 1]. К.Ф. Смирнов датировал находки V в. до н.э. [Смирнов, 1964, рис. 34], М.А. ОчирГоряева - концом VI - началом V в. до н.э. [Очир-Горяева, 2006, с. 96, 100-101].

Тип 1.1.3. Металлический налобник в виде круглой пластины диаметром 4,2 см с ажурным рельефным изображением фигуры волка, свернувшегося кольцом (рис. 1,12). В районе лопатки выполнено рельефное изображение профиля головы грифона. На обратной стороне налобника имеется петля для продевания ремня. Обнаружен в 100 м к юго-западу от кург. 1 могильника Филипповка I [Яблонский, 2013, с. 224, № 3133].

Тип 1.1.4. Металлический налобник (рис. 1,13 ) в виде пластины, передающей фор- 
V.N. Myshkin. Horse Forehead Pieces from Nomadic Barrows of the Scythian Time in the Southern Urals

му, которая может быть интерпретирована «одновременно как фигура копытного (оленя?) с подогнутой задней ногой и вывернутой передней ногой (ноги зверя при этом, в свою очередь, трансформированы в головы птиц с длинным загнутым клювом и ступенчатой восковицей), так и в качестве обособленной ноги со свисающим копытом с акцентированным рудиментарным пальцем-“шпорой”, превращенным опять-таки в птичью голову» [Кантарович, Яблонский, 2009, с. 78]. На обратной стороне налобника имеется петля для крепления к ремню узды. Этот налобник обнаружен в составе набора конского снаряжения, находившегося в юго-западной части кург. 3 Филипповского I могильника [Пшеничнюк, 2012 , с. 32 , рис. 56,7]. Датирован второй - третьей четвертями IV в. до н.э. [Кантарович, Яблонский, 2009, с. 78].

Тип 1.1.5. Металлический пластинчатый налобник (рис. 1,11), представляющий собой очень схематичное изображение припавшего на передние лапы хищника с вывернутой задней частью и закинутой на спину лапой. Один налобник этого типа обнаружен в юго-западной поле кург. 3 Филипповского I могильника [Пшеничнюк, 2012, с. 32, рис. 56,6].

1.2. Пластинчатые налобники без зооморфных изображений

Тип 1.2.1. Металлический налобник в виде плоской круглой в плане пластины диаметром 3,5 см, имеющей на обратной стороне петлю для продевания ремня (рис. 2,1). Обнаружен в кург. 6 могильника Таксай 1, датированном концом VI - началом V в. до н.э. [Лукпанова, 2014, с. 151,$156 ;$ рис. 5,5$]$.

Тип 1.2.2. Металлический налобник (рис. 2,2 ) в виде круглой в плане пластины, центральная часть которой представляет собой полусферическую выпуклость. Центральная часть отделена от периферийной вдавлениями в виде концентрических окружностей и валиком между ними. По краю пластины также нанесены вдавление и валик в виде концентрических окружностей. Диаметр пластины 4 см. Налобник обнаружен в 100 м к юго-западу от кург. 1 Филипповского I могильника [Яблонский, 2013, с. 223, № 3129]. А.Х. Пшеничнюк датировал этот курган началом IV в. до н.э. [Пшеничнюк, 2012, с. 87]. Предложена более широкая датировка указанного комплекса, ох- ватывающая период с конца V в. до н.э. по середину IV в. до н.э. [Трейстер, Шемаханская, Яблонский, 2012, с. 85].

Тип 1.2.3. Металлический налобник (рис. 2,4), выполненный в виде пластины, верхняя часть которой в плане круглая, а нижняя - подпрямоугольная с вогнутым нижним краем. Возможно, в нижней части подпрямоугольная пластина обломана. Не исключено, что эта часть налобника веерообразно расширялась. В центре верхней округлой части имеется рельефная полусферическая выпуклость. Она отделена от остальной части пластины валиком и двумя углублениями в виде концентрических окружностей. Кольцевидное углубление проходит также по краю верхнего округлого щитка налобника. На пространстве между кольцевидными углублениями располагаются отверстия треугольной формы. Такой налобник обнаружен в 100 м к югозападу от кург. 1 Филипповского могильника [Яблонский, 2013, с. 223, № 3131], который датирован началом IV в. до н.э. [Пшеничнюк, 2012, с. 87], а также концом V в. до н.э. серединой IV в. до н.э. [Трейстер, Шемаханская, Яблонский, 2012, с. 85].

Тип 1.2.4. Два металлических налобника (рис. 2,5,6), выполненных в виде сравнительно небольших удлиненных пластин, длинные стороны которых прямые или слегка вогнутые в средней части, короткие - прямые с трапециевидным выступом или выступающие углом. Один из налобников (рис. 2,5), обнаруженный в погр. 3 кург. 15 могильника Филипповка I [Яблонский, 2013, с. 175, № 2147], имеет расширение в средней части. Края расширения вогнуты и возле них проделаны дуговидные отверстия. На одном из концов имеется сквозное отверстие округлой формы. У второго налобника этого типа, происходящего из кург. 10 могильника Переволочан, расширения с вогнутыми краями расположены около концов пластины, а отверстия только обозначены дуговидными выемками (рис. 2,6). Один из концов украшен параллельно расположенными выемками. На внутренней стороне налобников имеется петля для продевания ремня. Длина филипповского налобника 15,9 см, переволочанского - 10,2 см. Второй половиной $\mathrm{V}-\mathrm{IV}$ в. до н.э. датирован кург. 15 Филипповского I могильника [Яблонский, 2008, 
c. 173]. Курган 10 могильника Переволочан датирован второй половиной IV в. до н.э. [Сиротин, 2016, с. 259]

Тип 1.2.5. Металлический налобник (рис. 2,7) в виде очень длинной пластины (длина 32,2 см), имеющей вогнутые длинные стороны и прямые короткие. Этот налобник обнаружен в 150-160 м к западу от кург. 1 могильника Филипповка и, скорее всего, связан с этим погребальным комплексом. Курган датирован началом IV в. до н.э. [Пшеничнюк, 2012. с. 87] и временем в пределах конца $\mathrm{V}$ в. до н.э. - середины IV в. до н.э. [Трейстер, Шемаханская, Яблонский, 2012, с. 85].

Тип 1.2.6. Металлический налобник в виде плоской пластины, имеющей форму ромба с одним усеченным острым углом (рис. 2,3). Его длина 6,5 см. Обнаружен в кург. 6 могильника Таксай, датированного концом VI - началом V в. до н.э. [Лукпанова, 2014, с. 151, 156, рис. 6,5].

Тип 1.2.7. Металлические налобники (рис. 2,8-11), выполненные в виде пластин, имеющих симметрично дугообразно выгнутые короткие и вогнутые длинные стороны. Эти налобники условно можно назвать «лабрисовидными». В центральной части на одной из коротких дуговидно выгнутых сторон имеется петля для продевания ремня. Их длина, судя по нефрагментированным экземплярам, составляет примерно 27-32 см, максимальная ширина до кончиков дуговидно изогнутых сторон около 18-25 см. К данному типу следует отнести четыре экземпляра из Большого Климовского кургана [Таиров, 2000, рис. 43,10-13]. А.Д. Таиров включил этот курган в число памятников второй половины VIпервой половины V в. до н.э. [Таиров, 2004], в том числе благодаря наличию рассматриваемых налобников, аналогичных некоторым экземплярам, которые, как полагали, происходят из Келермесских курганов конца VII - начала VI в. до н.э. [Мурзин, Черненко, 1980, с. 156]. И.И. Марченко и Н.Ю. Лимберис отметили, что такие налобники были исключены Л.К. Галаниной из числа келермесских древностей. По данным этих авторов, только один экземпляр этого типа налобников встречен в хорошо датированном комплексе. Он происходит из погребения 238в могильника Старокорсунского городища № 2. Это захоронение по най- денным в нем кносской (?) амфоре и средиземноморской амфоре неустановленного центра производства может быть датировано концом IV в. до н.э. Еще один такой налобник из Прикубанского могильника, найденный вне погребального комплекса, может быть отнесен к IV - началу III в. до н.э., так как время существования данного некрополя, определенное по более чем 300 амфорам различных типов, охватывает именно указанный период. При этом амфоры конца IV - начала III в. до н.э. из исследованных погребений составляют минимальный процент от тех, которые датированы временем в пределах IV в. до н.э. [Марченко, Лимберис, 2009, с. 70, 73]. М.А. Очир-Горяева отнесла комплекс находок конского снаряжения из Большого Климовского кургана к третьей группе, которую датировала концом V - IV в. до н.э. [Очир-Горяева, 2012, c. 269-271, ил. 285].

2. Стержневидные и стержневиднопластинчатые налобники

Тип 2.1. Металлические (известные в настоящее время - все железные) налобники (рис. 3,1-19), верхняя часть которых представляет собой, как правило, округлый в сечении стержень, согнутый в виде петли или дуги и заканчивающийся шаровидным утолщением, а нижняя раскована в виде удлиненной пластины (лопасти) каплевидной в плане формы. Реже нижняя часть таких налобников стержневидная. Иногда нижняя часть представляет собой стержень, заканчивающийся каплевидной в плане лопастью. Место соединения верхней и нижней частей выполнено в виде кольца для продевания уздечного ремня. Плоскость кольца перпендикулярна плоскости нижней лопасти, а ребро чаще всего соприкасается с шаровидным окончанием верхней загнутой части. Длина налобников варьируется в пределах от 10,2 до 15,9 см. Рассматриваемая выборка включает в себя 19 налобников этого типа. Некоторые из них обнаружены в памятниках, датированных концом VI - V в. до н.э. Один экземпляр (рис. 3,1 ) обнаружен в погр. 2 кург. 2 могильника Мечет-Сай [Смирнов, Петренко, 1963, с. 30, табл. 17,29]. Оно датировано К.Ф. Смирновым концом VI - началом V в. до н.э. [Смирнов, 1975, с. 90]. Второй (рис. 3,2) найден в погр. 1 кург. 7 Ново-Кумакского могильника 
V.N. Myshkin. Horse Forehead Pieces from Nomadic Barrows of the Scythian Time in the Southern Urals

[Мошкова, 1962, рис. 6,7]. Комплекс может быть датирован V в. до н.э. [Мошкова, 1962, с. 223-225], возможно, началом V в. до н.э. [Смирнов, Петренко, 1963, с. 17]. В состав погребального инвентаря Большого Климовского кургана также входил налобник этого типа (рис. 3,3). Указанный курган датирован А.Д. Таировым концом VI - началом V в. до н.э. [Таиров, 2000 , с. $140-155 ; 2004$, с. $3-21]$. М.А. Очир-Горяева включила находки конского снаряжения из Большого Климовского кургана в группу, дата которой, по ее мнению, приходится на конец V - IV в. до н.э. [ОчирГоряева, 2012, с. 269-271, ил. 285]. Еще 16 налобников этого типа (рис. 3,4-19) обнаружены в погребальных памятниках южноуральских кочевников, уверенно датированных временем в пределах второй половины V - IV в. до н.э. Они найдены в кургане у хут. Веселый I близ с. Ак-Булак [Смирнов, 1964, рис. 38,6-7, c. 58], в насыпи и погр. 2 кург. 10 могильника Переволочан [Пшеничнюк, 1995, с. 81, 93, рис. $11,11-12 ; 14,20]$, погр. 5 кург. 11 этого же могильника [Сиротин, 2010, с. 332-333, 337, рис. 6,5], Аваласовском 3 кургане [Сиротин, 2013 , с. 166 ; 2015 , с. 250 , рис. 2 ,6]; около кург. 1 и в погр. 1 кург. 11 могильника Филипповка I [Яблонский, 2008, с. 173; 2013, с. 127, 131-132, 226, № 1307, 1543, 1544, 1547, 1558, 3144; Пшеничнюк, 2012, с. 87]. По всей видимости, к этой же группе следует отнести налобник (рис. 3,9 ) из кург. 5 могильника Ивановка I, опубликованный С.В. Сиротиным [Сиротин, 2015, с. 250, рис. 3,7].

3. Налобники в виде зооморфных изображений, представляющих собой круглую скульптуру

Тип 3.1. Металлический налобник (рис. 3,20 ), представляющий собой протому архара. Изображение головы, передней части туловища и выставленных вперед передних ног реалистичное, выполнено в круглой скульптуpe. В налобнике имеется сквозное отверстие, проходящее в районе лопаток животного. Обнаружен в погр. 1 кург. 15 могильника Филипповка I, датированном второй половиной V IV в. до н.э. [Балахванцев, Яблонский, 2007, c. 148, рис. 7; Яблонский, 2013, с. 142, № 1681].

Судя по датам, принятым в настоящее время для погребальных комплексов Южного Приуралья, содержавших конские на- лобники, последние можно разделить на две группы.

В первую группу следует включить крупные налобники (рис. 1,1-6) в виде трапециевидных или подпрямоугольных пластин с изображением голов хищных птиц в профиль (тип 1.1.1); в виде удлиненных пластин сравнительно небольших размеров (рис. 1,7-10), короткие верхние стороны которых имеют завершение в виде полусферических блях и стилизованного изображения профиля головы хищной птицы (тип 1.1.2); металлические налобники (рис. 2,1,3) в виде плоских пластин, имеющих в плане круглую (тип 1.2.1) или ромбическую (тип 1.2.6) форму. Время использования налобников этих типов приходится на конец VI - V в. до н.э. Число налобников указанных типов сравнительно невелико. Возможно, это в значительной мере обусловлено тем обстоятельством, что для украшения налобных ремней оголовья в этот период часто использовались различные бляшки-подвески [Мышкин, 2014, с. 605; 2015]. Вторая группа объединяет типы налобников, которые получили распространение в период, приходящийся на конец V - IV в. до н.э. Это налобники в виде круглой ажурной пластины (рис. 1,12 ) с рельефным изображением фигуры волка (тип 1.1.3), пластины, имеющие форму (рис. 1,13), которая может быть интерпретирована как фигура копытного (оленя?) и одновременно как обособленная нога со свисающим копытом (тип 1.1.4); схематичного изображения припавшего на передние лапы хищника (рис. 1,11 ) с вывернутой задней частью и закинутой на спину лапой (тип 1.1.5); круглой металлической пластины с полусферической выпуклостью в центральной части (рис. 2,2) и геометрическим орнаментом (тип 1.2.2); пластины, верхняя часть которой в плане круглая, а нижняя - подпрямоугольная (рис. 2,4) с вогнутым нижним краем (тип 1.2.3); удлиненных подпрямоугольных пластин (рис. 2,5,6) сравнительно небольших размеров (тип 1.2.4) или очень длинных (рис. 2,7), отнесенных к типу 1.2.5; «лабрисовидных» пластинчатых (рис. 2,8-11), выделенных в тип 1.2.7; в виде стержня (рис. 3,119), верхняя часть которого согнута петлей или дугой и заканчивается шаровидным утолщением, а нижняя раскована в виде удлинен- 
ной пластины (тип 2.1); а также в виде протомы архара (рис. 3,20), выполненной в круглой скульптуре (тип 3.1). Следует отметить, что налобники типа 2.1 в незначительном количестве встречаются в памятниках, датированных концом VI - V в. до н.э. Речь идет об одном экземпляре (рис. 3,1 ) из погр. 2 кург. 2 могильника Мечет-Сай, которое датировано К.Ф. Смирновым концом VI - началом V в. до н.э. [Смирнов, 1975, с. 90], и находке в погр. 1 кург. 7 Ново-Кумакского могильника [Мошкова, 1962, рис. 6,7], дата которого приходится на V в. до н.э. [Мошкова, 1962, с. 223 225], возможно, на его начало [Смирнов, Петренко, 1963, с. 17]. В целом необходимо констатировать, что состав двух указанных хронологических групп демонстрирует существенные различия в облике конских налобников, что, возможно, было обусловлено этнокультурными изменениями в обществе кочевников Южного Приуралья на рубеже VIV вв. до н.э., в том числе в характере и направлении внешних связей.

\section{Заключение}

Предметы, использовавшиеся кочевниками Южного Приуралья во второй половине VI - IV в. до н.э. и интерпретируемые в археологической литературе как налобники, характеризуются значительным разнообразием формы. Это позволяет выделить довольно большое количество типов данного элемента конского снаряжения. В настоящее время, основываясь на датах погребальных комплексов, содержавших налобники, представляется возможным разделить эти предметы на две группы, которые относятся к разным периодам существования культуры южноуральских номадов. Время использования кочевниками налобников одной группы приходится на конец VI - V в. до н.э. В этот период наиболее распространенными были налобники в виде достаточно крупных трапециевидных или подпрямоугольных пластин с изображением голов хищных птиц в профиль на одной или обеих коротких сторонах (тип 1.1.1). Во вторую группу включены типы, получившие распространение у степных племен Южного Приуралья в основном в конце V - IV в. до н.э. Наиболее распространенным типом в это время являются налобники в виде стержня, верхняя часть которого согнута петлей или дугой и заканчивается шаровидным утолщением, а нижняя раскована в виде удлиненной пластины (тип 2.1), которые стали использоваться, по всей видимости, еще в предшествующий период (конец VI - V в. до н.э.). Смена номенклатуры типов конских налобников обусловлена, вероятно, этнокультурными изменениями, происходившими в обществе кочевников Южного Приуралья в конце V начале IV в. до н.э., в том числе в характере и направленности внешних этнокультурных связей. 


\section{ИЛЛЮСТРАЦИИ}
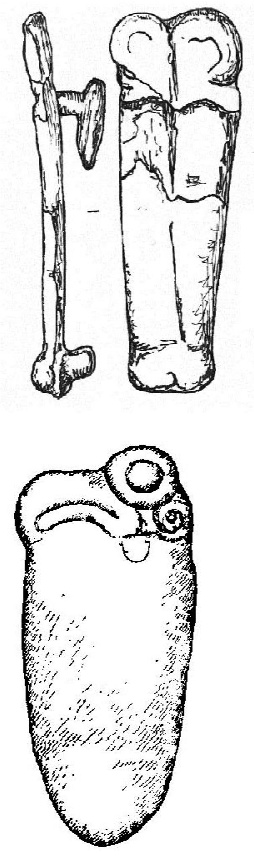

6
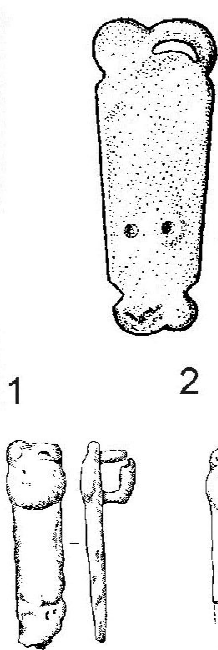

7

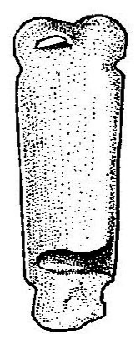

3

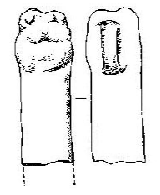

8

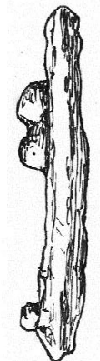

4

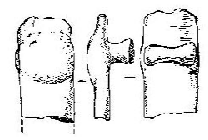

9

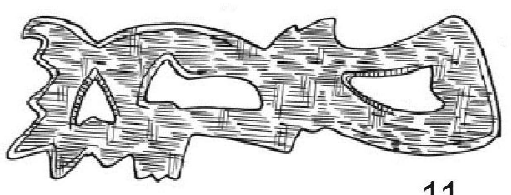

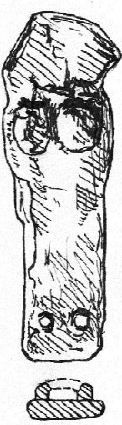

5
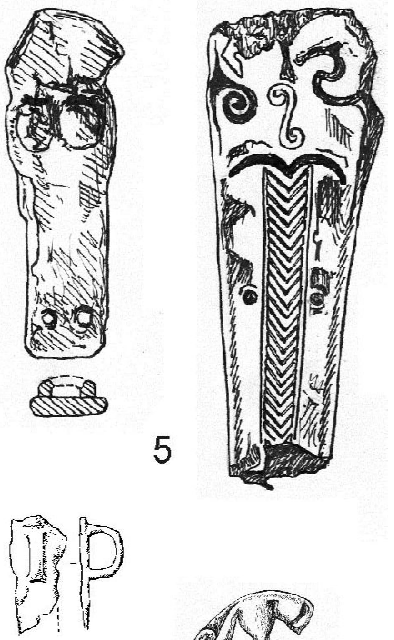

10

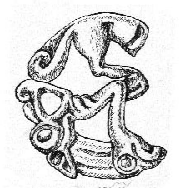

11

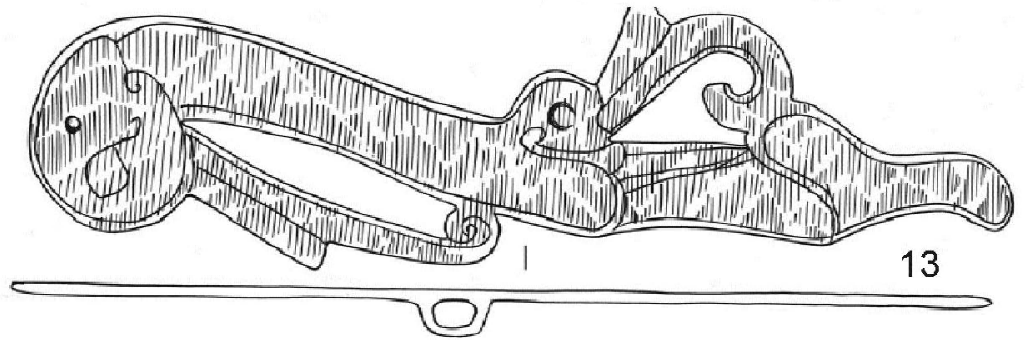

2

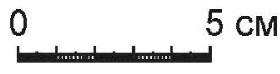

Рис. 1. Налобники из курганов кочевников Южного Приуралья:

1 - Покровка 2, кург. 2 [Моргунова, Трунаева, 1993, рис. 18,16]; 2-3 - курган у хут. Черниговский [Смирнов, Петренко, 1963, табл. 17,3-4]; 4 - Ново-Кумакский, кург. 19, погр. 2 [Смирнов, 1977, табл. 11,20]; 5 - Бесоба, кург. 9 [Кадырбаев, 1984, рис. 5,3]; 6 - кург. 1 у с. Покровка (раскопки 1911 г.)

[Смирнов, 1964, рис. 16,1a]; 7-10 - Пятимары II, кург. 5 [Смирнов, 1961, рис. 54]; 11, 13 - Филипповка I, кург. 3 [Пшеничнюк, 2012, рис. 56,6,7]; 12 - Филипповка I, кург. 1, околокурганное пространство

[Яблонский, 2013, № 3133] (1 - бронза и золото, 2-3, 6-13 - бронза, 4 - железо, 5 - железо и золото)

Fig. 1. Horse forehead pieces from nomadic barrows of the Southern Urals:

1 - Pokrovka 2, barrow 2 [Morgunova, Trunaeva, 1993, fig. 18,16]; 2-3 - barrow in the farmstead Chernigovskiy

[Smirnov, Petrenko, 1963, tab. 17,3-4]; 4 - Novo-Kumak, barrow 19, burial 2 [Smirnov, 1977, tab. 11,20];

5 - Besoba, barrow 9 [Kadyrbaev, 1984, fig. 5,3]; 6 - barrow 1 in the village Pokrovka (excavations of 1911)

[Smirnov, 1964, fig. 16,1a]; 7-10 - Pyatimary II, barrow 5 [Smirnov, 1961, fig. 54]; 11, 13 - Filippovka I, barrow 3

[Pshenichnyuk, 2012, fig. 56,6,7]; 12 - Filippovka I, barrow 1, near-barrow space

[Yablonsky, 2013, no. 3133] (1 - bronze and gold, 2-3, 6-13 - bronze, 4 - iron, 5 - iron and gold) 


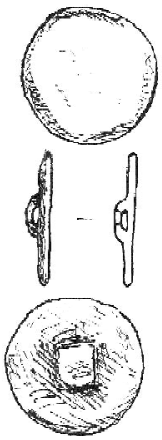

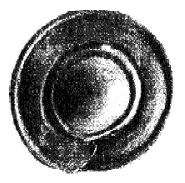

2

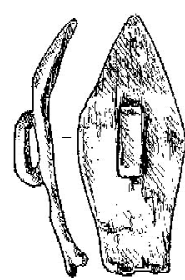

3

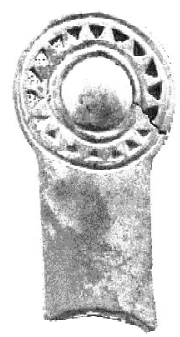

4 $5 \mathrm{~cm}$

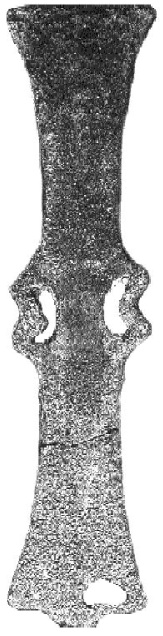

5

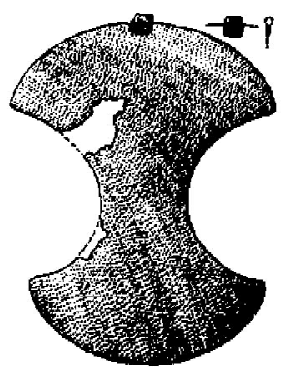

9

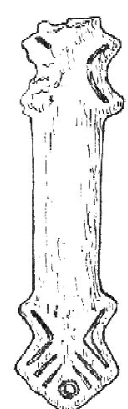

6

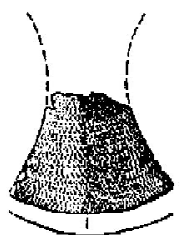

11

Рис. 2. Налобники из курганов кочевников Южного Приуралья:

1, 3 - Таксай 1, кург. 6 [Лукпанова, 2014, рис. 5,5, 6,5]; 2, 4 - Филипповка I, кург. 1, околокурганное пространство [Яблонский, 2013, № 3129, 3131]; 5 - Филипповка I, кург. 15, погр. 3 [Яблонский, 2013, № 2147];

6 - Переволочан, кург. 10 [Пшеничнюк, 1995, рис. 11,15]; 7 - Филипповка I, кург. 1, околокурганное пространство

[Яблонский, 2013, № 3150]; 8-11 - большой Климовский курган [Таиров, 2000, рис. 43,10-13] (1-11 - бронза)

Fig. 2. Horse forehead pieces from nomadic barrows of the Southern Urals:

1, 3 - Taksay 1, barrow 6 [Lukpanova, 2014, fig. 5,5, 6,5]; 2, 4 - Filippovka I, barrow 1, near-barrow space [Yablonsky, 2013, no. 3129, 3131]; 5 - Filippovka I, barrow 15, burial 3 [Yablonsky, 2013, no. 2147];

6 - Perevolochan, barrow 10 [Pshenichnyuk, 1995, fig. 11,15]; 7 - Filippovka I, barrow 1, near-barrow space [Yablonsky, 2013, no. 3150]; 8-11 - The Large Klimovsky barrow [Tairov, 2000, fig. 43,10-13] (1-11 - bronze) 


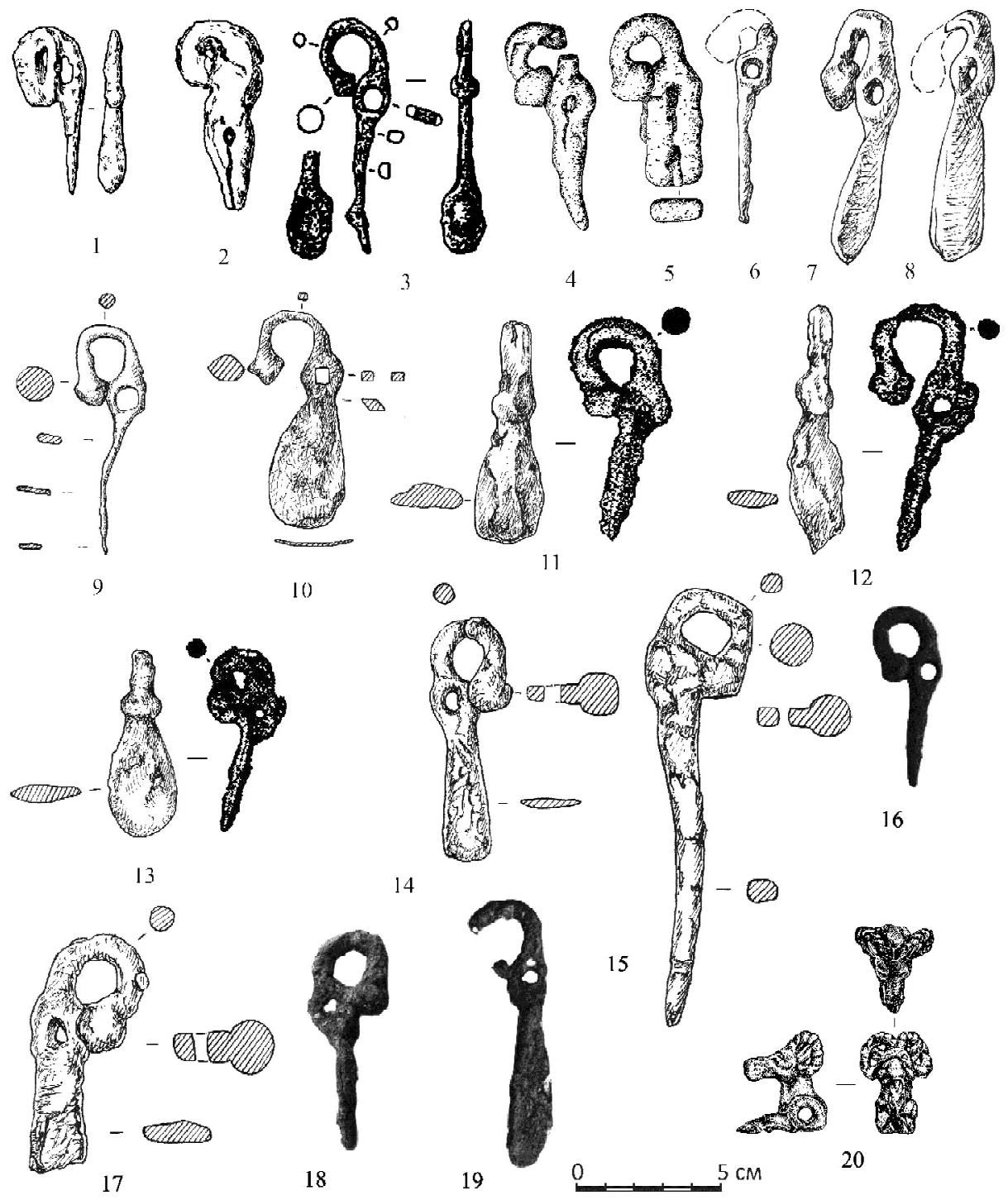

Рис. 3. Налобники из курганов кочевников Южного Приуралья:

1 - Мечет-Сай, кург. 2, погр. 2 [Смирнов, Петренко, 1963, табл. 17,29]; 2 - Ново-Кумакский, кург. 7, погр. 1 [Мошкова, 1962, рис. 6,7]; 3 - Большой Климовский курган [Таиров, 2000, рис. 43,1];

4-5 - курган у хут. Веселый I, близ с. Ак-Булак [Смирнов, 1964, рис. 38,6-7]; 6 - Переволочан, кург. 10, погр. 2

[Пшеничнюк, 1995, рис. 11,11]; 7-8 - Переволочан, кург. 10, пола [Пшеничнюк, 1995, рис 11,12; 14,12];

9 - Ивановка I, кург. 5, насыпь [Сиротин, 2015, рис. 3,7]; 10 - Аваласовские курганы, кург. 5, насыпь

[Сиротин, 2015, рис. 2,6]; 11-13 - Переволочан, кург. 11, погр. 5 [Сиротин, 2010, рис. 6,5];

14-15, 17-19 - Филипповка I, кург. 11, погр. 1 (14-15, 17 - [Яблонский, 2008, рис. 3,A,Б6,Б7];

18-19 - [Яблонский, 2013, с. 133-134, № 1543, 1544]); 16 - Филипповка I, кург. 1, околокурганное пространство

[Яблонский, 2013, с. 226, № 3144]; 20 - Филипповка I, кург. 15, погр. 1 [Балахванцев, Яблонский, 2007, рис. 7] (1-19- железо; 20 - бронза)

Fig. 3. Horse forehead pieces from nomadic barrows of the Southern Urals:

1 - Mechet-Sai, barrow 2, burial 2 [Smirnov, Petrenko, 1963, tab. 17,29]; 2 - Novo-Kumak, barrow 7, burial 1 [Moshkova, 1962, fig. 6,7]; 3 - The Large Klimovsky barrow [Tairov, 2000, fig. 43,1];

4-5 - barrow near the farmstead Veselyy I, near the village Ak-Bulak [Smirnov, 1964, fig. 38,6-7];

6 - Perevolochan, barrow 10, burial 2 [Pshenichnyuk, 1995, fig. 11,11]; 7-8 - Perevolochan, barrow 10, mound [Pshenichnyuk, 1995, fig. 11,12, 14,12]; 9 - Ivanovka I, barrow 5, mound [Sirotin, 2015, fig. 3,7];

10 - Avalassovsky barrows, barrow 5, mound [Sirotin, 2015, fig. 2,6]; 11-13 - Perevolochan, barrow 11, burial 5

[Sirotin, 2010, fig. 6,5]; 14-15, 17-19 - Filippovka I, barrow 11, burial 1 (14-15, 17 - [Yablonsky, 2008, fig. 3, A, B6, B7];

18-19 - [Yablonsky, 2013, pp. 133-134, no. 1543, 1544]); 16 - Filippovka I, barrow 1, near-barrow space

[Yablonsky, 2013, p. 226, no. 3144]; 20 - Filippovka I, barrow 15, burial 1 [Balakhvantsev, Yablonsky, 2007, fig. 7] (1-19 - iron, 20 - bronze) 


\section{ПРИМЕЧАНИЕ}

${ }^{1}$ Работа выполнена в рамках государственного задания Министерства образования и науки РФ № 33.1907. 2017/ПЧ «Традиционные и инновационные модели развития древнего населения Поволжья».

\section{СПИСОК ЛИТЕРАТУРЫ}

Балахванцев А. С., Яблонский Л. Т., 2007. Ахеменидская эмаль из Филипповки (проблема хронологии памятника) // Российская археология. № 1. С. 143-149.

Берлизов Н. Е., 2011. Ритмы Сарматии. Савроматосарматские племена Южной России в VII в. до н.э. - V в. н.э. Ч. І. Краснодар : КГУКИ ; Парабеллум. 320 с.

Кадырбаев М. К., 1984. Курганные некрополи верховьев р. Илек // Древности Евразии в скифосарматское время. М. : Наука. С. 84-107.

Кантарович А. Р., Яблонский Л. Т., 2009. О северопричерноморских и северокавказских параллелях изображениям в скифо-сибирском зверином стиле на предметах из Филипповских курганов // Нижневолжский археологический вестник. Вып. 10. С. 73-99.

Лукпанова Я. А., 2014. Комплексы конского снаряжения кургана № 6 Таксай 1 (предварительный обзор) // Всадники великой степи: традиции и новации. Астана : Издат. группа ФИА им. А.Х. Маргулана в г. Астана. С. 149-160.

Марченко И. И., Лимберис Н. Ю., 2009. Пластинчатые конские налобники из Прикубанья // Археология, этнография и антропология Евразии. № 3 (39). С. 69-74.

Моргунова Н. Л., Трунаева Т. Н., 1993. Раскопки кургана 2 могильника Покровка 2 в 1991 году // Курганы левобережного Илека. М. : Изд-во ИА РАН. С. 15-17.

Мошкова М. Г., 1962. Ново-Кумакский курганный могильник близ г. Орска // Памятники скифосарматской культуры : Материалы и исследования по археологии СССР. № 115. М. : АН CCCP. C. 204-241.

Мурзин В. Ю., Черненко Е. В., 1980. О средствах защиты боевого коня в скифское время // Скифия и Кавказ. Киев : Наукова думка. С. 155-167.

Мышкин В. Н., 2014. К проблеме типологии одной группы уздечных бляшек у кочевников Южного Урала в скифское время // Известия Самарского научного центра Российской академии наук. Т. 16, № 3. Ч. 2. С. 605-610.

Мышкин В. Н., 2015. О некоторых категориях украшений наносных и налобных ремней конской узды у кочевников Южного Урала в скифское время // Известия Самарского научного центра Российской академии наук. Т. 17, № 3. С. 273-280.

Очир-Горяева М. А., 2006. Уздечные наборы скифской эпохи из Южного Приуралья // Liber archaeologicae : сб. ст., посвящ. 60-летию Б.А. Раева. Краснодар; Ростов н/Д : Изд-во ЮНЦ РАН. С. 94-106.

Очир-Горяева М. А., 2012. Древние всадники степей Евразии. М. : Таус. 472 с.

Пшеничнюк А. Х., 1995. Переволочанский могильник // Курганы кочевников Южного Урала. Уфа: Гилем. С. 62-96.

Пшеничнюк А. X., 2012. Филипповка: некрополь кочевой знати IV века до н.э. на Южном Урале. Уфа : ИИЯЛ УНЦ РАН. 280 с.

Сиротин С. В., 2010. Курган № 11 курганного могильника Переволочан в Зауральской Башкирии // Археология и палеоантропология Евразийских степей и сопредельных территорий. М. : Таус. С. 323-338.

Сиротин С. В., 2013. Катакомбные погребальные комплексы IV в. до н.э. могильника «Авласовские курганы» из Южного Зауралья // Исторические, философские, политические и юридические науки, культурология и искусствоведение. Вопросы теории и практики. Т. 11, ч. 2. Тамбов : Грамота. С. 163-169.

Сиротин С. В., 2015. Предметы конской сбруи из насыпей курганов ранних кочевников Южного Урала (по материалам раскопок 20082013 годов) // Этнические взаимодействия на Южном Урале : материалы VI Всерос. науч. конф. Челябинск : Челяб. гос. краевед. музей. C. 247-255.

Сиротин С. В., 2016. Об относительной хронологии и датировке Переволочан I // Константин Федорович Смирнов и современные проблемы сарматской археологии : материалы IX Междунар. науч. конф. «Проблемы сарматской археологии и истории», посвящ. 100-летию со дня рождения Константина Федоровича Смирнова (Оренбург, 12-15 мая 2016 г.). Оренбург : Изд-во ОГПУ. С. 253-264.

Смирнов К. Ф., 1961. Вооружение савроматов // Материалы и исследования по археологии СССР. № 101. М. : Изд-во Академии наук СССР. $168 \mathrm{c}$.

Смирнов К. Ф., 1964. Савроматы. Ранняя история и культура сарматов. М. : Наука. 379 с.

Смирнов К. Ф., 1975. Сарматы на Илеке. М. : Наука. $175 \mathrm{c}$.

Смирнов К. Ф., 1977. Орские курганы ранних кочевников // Исследования по археологии Южного Урала. Уфа: Изд-во БФАН СССР. С. 3-51. 
V.N. Myshkin. Horse Forehead Pieces from Nomadic Barrows of the Scythian Time in the Southern Urals

Смирнов К. Ф., Петренко В. Г., 1963. Савроматы Поволжья и Южного Приуралья // Свод археологических источников. Вып. Д1-9. М. : Наука. 40 с.

Таиров А. Д., 2000. Ранний железный век // Древняя история Южного Зауралья. Т. II. Ранний железный век и средневековье. Челябинск : Изд-во ЮУрГУ. С. 3-205.

Таиров А. Д., 2004. Периодизация памятников ранних кочевников Южного Зауралья 7-2 вв. до н.э. // Сарматские культуры Евразии: проблемы региональной хронологии : Доклады к 5 Междунар. конф. «Проблемы сарматской археологии и истории». Краснодар. С. 3-21.

Трейстер М. Т., Шемаханская М. С., Яблонский Л. Т., 2012. Комплексы с предметами ахеменидского круга могильника Филипповка-I // Влияния ахеменидской культуры в Южном Приуралье (V-III вв. до н.э.). T. II. М. : Таус. С. 85-156.

Яблонский Л. Т., 2008. Новые раскопки Филипповского могильника и проблема формирования раннесарматской культуры Южного Приуралья // Материалы Междунар. науч. конф. «Ранние кочевники Южного Приуралья в свете новейших археологических открытий» (Оренбург, 21-25 апр. 2008 г.). Оренбург : Изд-во ОГПУ. С. 170-176.

Яблонский Л. Т., 2013. Золото сарматских вождей. Элитный некрополь Филипповка I (по материалам раскопок 2004-2009 гг.). Каталог коллекции. Кн. 1. М. : ИА РАН. 232 с.

\section{REFERENCES}

Balakhvantsev A.S., Yablonskiy L.T., 2007. Achaemenid Enamel from Filippovka and the Problem of the Monument's Chronology. Rossiyskaya arkheologiya, no. 1, pp. 143-149. (in Russian).

Berlizov N.E., 2011. Rhythms of Sarmatia. The Sauromato-Sarmatian Tribes of Southern Russia in the $7^{\text {th }}$ century $B C-5^{\text {th }}$ century $A D$. Part I. Krasnodar, KGUKI; Parabellum Publ. 320 p. (in Russian).

Kadyrbaev M.K., 1984. Barrow Necropolises of the Upper Reaches of the Ilek River. Drevnosti Evrazii v skifo-sarmatskoe vremya. Moscow, Nauka Publ., pp. 84-107. (in Russian).

Kantarovich A.R., Yablonskiy L.T., 2009. North-Pontic and North-Caucasian Analogies to the ScythoSiberian Style Images Decorating the Objects from the Filippovka Barrows. The Lower Volga Archaeological Bulletin, iss. 10, pp. 73-99. (in Russian).

Lukpanova Y.A., 2014. Horse equipment sets of kurgan 6 of complex Taksai 1 (preliminary overview).
Vsadniki velikoj stepi: tradicii $i$ novacii. Astana, Izdatel'skaya gruppa FIA im. A.H. Margulana v g. Astana, pp. 149-160. (in Russian).

Marchenko I.I., Lamberis N.Yu., 2009. Laminar Horse Forehead Pieces from the Kuban Region. Archaeology, Ethnology and Anthropology of Eurasia, no. 3 (39), pp. 69-74. (in Russian).

Morgunova N.L., Trunaeva T.N., 1993. Excavation of Barrow 2 of the Burial Mound Pokrovka 2 in 1991. Kurgany levoberezhnogo Ileka. Moscow, IA RAnN Publ., pp. 15-17. (in Russian).

Moshkova M.G., 1962. Novo-Kumak Burial Mound near the City of Orsk. Pamyatniki skifosarmatskoy kultury. Materialy i issledovaniya po arkheologii SSSR, no. 115. Moscow, AN SSSR Publ., pp. 204-241. (in Russian).

Murzin V.Yu., Chernenko E.V., 1980. The Means of Protection of a Fighting Horse in the Scythian Time. Skifiya i Kavkaz. Kiev, Naukova dumka Publ., pp. 155-167. (in Russian).

Myshkin V.N., 2014. To the Problem of Typology of One Group of Bridle Horse Plaques of the Nomads from the Southern Ural in the Scythian Time. Izvestiya Samarskogo nauchnogo tsentra Rossiyskoy akademii nauk, vol. 16, no. 3, part 2, pp. 605-610. (in Russian).

Myshkin V.N., 2015. On Some Kinds of Decorations of Nosebands and Brow Bands of Horse Bridle of the Southern Ural Nomads in the Scythian Times. Izvestiya Samarskogo nauchnogo tsentra Rossiyskoy akademii nauk, vol. 17, no. 3, pp. 273-280. (in Russian).

Ochir-Goryaeva M.A., 2006. Bridle Sets of the Scythian Epoch from the Southern Urals. Liber archaeologicae: sbornik statey, posvyashchennyy 60-letiyu B.A. Raeva. Krasnodar; Rostov-on-Don, Izd-vo YuNTs RAN, pp. 94-106. (in Russian).

Ochir-Goryaeva M.A., 2012. The Ancient Horsemen of the Steppes of Eurasia. Moscow, Taus Publ. 472 p. (in Russian).

Pshenichnyuk A.Kh., 1995. The Perevolochan Burial Mound. Kurgany kochevnikov Yuzhnogo Urala. Ufa, Gilem Publ., pp. 62-96. (in Russian).

Pshenichnyuk A.Kh., 2012. Filippovka: Necropolis of the Nomadic Nobility of the $4^{\text {th }}$ Century BC in the Southern Urals. Ufa, IIYaL UNTs RAN Publ. 280 p. (in Russian).

Sirotin S.V., 2010. Barrow 11 of the Burial Mound Perevolochan in Trans-Ural Bashkiria. Arkheologiya i paleoantropologiya Evraziyskikh stepey i sopredelnykh territoriy. Moscow, Taus Publ., pp. 323-338. (in Russian).

Sirotin S.V., 2013. Catacomb Burial Complexes of the $4^{\text {th }}$ Century BC in the Burial Mound Avlasovskie 
kurgany in the Southern Urals. Istoricheskie, filosofskie, politicheskie i yuridicheskie nauki, kulturologiya i iskusstvovedenie. Voprosy teorii i praktiki, vol. 11, part 2. Tambov, Gramota Publ., pp. 163-169. (in Russian).

Sirotin S.V., 2015. Items of Horse Harness from Barrow Mounds of the Early Nomads of the Southern Urals (Based on the Materials of Excavations 20082013). Etnicheskie vzaimodeystviya na Yuzhnom Urale: materialy VI Vserossiyskoy nauchnoy konferentsii. Chelyabinsk, Izd-vo Chelyabinskogo gosudarstvennogo kraevedcheskogo muzeya, pp. 247-255. (in Russian).

Sirotin S.V., 2016. On the Relative Chronology and the Dating of Perevolochan I. Konstantin Fedorovich Smirnov i sovremennye problemy sarmatskoy arkheologii: materialy IX Mezhdunarodnoy nauchnoy konferentsii «Problemy sarmatskoj arkheologii $i$ istorii», posvyashchennoy 100-letiyu so dnya rozhdeniya Konstantina Fedorovicha Smirnova (Orenburg, 12-15 maya 2016 g.). Orenburg, Izd-vo OGPU, pp. 253-264. (in Russian).

Smirnov K.F., 1961. Weapons of the Sauromats. Materialy $i$ issledovaniya po arkheologii SSSR, no. 101. Moscow, Izd-vo AN SSSR. 168 p. (in Russian).

Smirnov K.F., 1964. The Sauromats. Early History and Culture of the Sarmatians. Moscow, Nauka Publ. 379 p. (in Russian).

Smirnov K.F., 1975. Sarmatians on the Ilek River. Moscow, Nauka Publ. 175 p. (in Russian).

Smirnov K.F., 1977. Barrows of the Early Nomads near the City of Orsk. Issledovaniya po arkheologii Yuzhnogo Urala. Ufa, Izd-vo BFAN SSSR, pp. 3-51. (in Russian).
Smirnov K.F., Petrenko V.G., 1963. The Sauromats of the Volga Region and the Southern Urals. Svod arkheologicheskikh istochnikov. Iss. D1-9. Moscow, Nauka Publ. 40 p. (in Russian).

Tairov A.D., 2000. The Early Iron Age. Drevnyaya istoriya Yuzhnogo Zauralya. T. II. Ranniy zheleznyy vek i srednevekovye. Chelyabinsk, Izd-vo YuUrGU, pp. 3-205. (in Russian).

Tairov A.D., 2004. The Periodization of Monuments of the Early Nomads of the Southern Trans-Urals of the $7^{\text {th }}-12^{\text {the }}$ Centuries BC. Sarmatskie kultury Evrazii: problemy regionalnoy khronologii: Doklady k 5 Mezhdunarodnoy konferentsii "Problemy sarmatskoy arkheologii i istorii". Krasnodar, pp. 3-21. (in Russian).

Treyster M.T., Shemakhanskaya M.S., Yablonskiy L.T., 2012. Complexes with the Objects of Achaemenid Circle of the Filippovka-I Burial Mound. Vliyaniya akhemenidskoy kultury $v$ Yuzhnom Priuralye (V-III vv. do n.e.). T. II. Moscow, Taus Publ., pp. 85-156. (in Russian).

Yablonskiy L.T., 2008. New Excavations of the Filippovka Burial Mound and the Problem of Formation of the Early Sarmatian Culture in the Southern Urals. Materialy mezhdunar. nauch. konf. "Rannie kochevniki Yuzhnogo Priuralya $v$ svete noveyshikh arkheologicheskikh otkrytiy" (Orenburg, 21-25 aprelya 2008 g.). Orenburg, Izd-vo OGPU, pp. 170-176. (in Russian).

Yablonskiy L.T., 2013. Gold of the Sarmatian Chiefs. Elite Necropolis Filippovka-I (Based on the Materials of Excavations, 2004-2009). Catalogue of the Collection. Book 1. Moscow, IA RAN Publ. 232 p. (in Russian).

\section{Information about the Author}

Vladimir N. Myshkin, Candidate of Sciences (History), Head of Archaeological Laboratory, Samara State University of Social Sciences and Education, Leninskaya St., 127, 443041 Samara, Russian Federation,vnm59@bk.ru.

\section{Информация об авторе}

Владимир Николаевич Мышкин, кандидат исторических наук, заведующий археологической лабораторией, Самарский государственный социально-педагогический университет, ул. Ленинская, 127, 443041 г. Самара, Российская Федерация, vnm59@bk.ru. 